\title{
Short-Day Photoperiod Increases Milk Yield in Cows with a Reduced Dry Period Length
}

\author{
J. M. Velasco, E. D. Reid, K. K. Fried, T. F. Gressley, ${ }^{1}$ R. L. Wallace, and G. E. Dahl' ${ }^{2,3}$ \\ Department of Animal Sciences, University of Illinois, Urbana 61801
}

\section{ABSTRACT}

Exposure of cows to a short-day photoperiod (SDPP; $8 \mathrm{~h}$ light:16 h dark) during a 60-d dry period increases milk yield in the subsequent lactation compared with cows exposed to a long-day photoperiod (LDPP; $16 \mathrm{~h}$ light:8 $\mathrm{h}$ dark). Whereas the traditional recommendation for dry period length is $60 \mathrm{~d}$, recent studies indicate that the dry period length can be reduced without depressing the yield in the next lactation. However, the optimal duration of the dry period appears to be between 40 and $60 \mathrm{~d}$, because fewer than $30 \mathrm{~d}$ could result in a significant loss of milk production. Our main objective was to determine whether treatment with SDPP combined with a reduced dry period length of $42 \mathrm{~d}$ would increase milk yield in the next lactation relative to treatment with LDPP, even though SDPP exposure was limited to $42 \mathrm{~d}$. Multiparous Holstein cows $(n=40)$ were randomly assigned to 1 of 2 treatments during the dry period: LDPP or SDPP. Each treatment group $(\mathrm{n}=20)$ was balanced according to the previous 305-d mature equivalent milk yield. To quantify plasma prolactin (PRL) concentration, blood samples were collected weekly during the dry period. Dry matter intake (DMI) was recorded during the dry period. Health was monitored weekly during the dry period and at calving. During lactation, milk yield and DMI were recorded for 120 and $42 \mathrm{~d}$, respectively. Cows exposed to SDPP calved $4.8 \mathrm{~d}$ earlier than cows exposed to LDPP and days dry averaged 37 and $42 \mathrm{~d}$ for cows exposed to SDPP and LDPP, respectively. Cows on SDPP consumed more dry matter $(17.0 \pm 1.1 \mathrm{~kg} / \mathrm{d})$ during the dry period than did cows on LDPP $(15.9 \pm 1.1 \mathrm{~kg} / \mathrm{d})$, but DMI after parturition did not differ. In the first $42 \mathrm{~d}$ of lactation, cows exposed to SDPP and LDPP consumed 18.0 and $17.7 \pm 1.4 \mathrm{~kg} / \mathrm{d}$, respectively. The periparturient PRL surge was greater in cows exposed to LDPP

Received January 17, 2008.

Accepted May 8, 2008.

${ }^{1}$ Current address: Department of Animal and Food Sciences, University of Delaware, Newark, DE 19716-2150.

${ }^{2}$ Corresponding author: gdahl@ufl.edu

${ }^{3}$ Current address: Department of Animal Sciences, University of Florida, POB 110910, Gainesville, FL 32611.
$(22.6 \pm 3.2 \mathrm{ng} / \mathrm{mL})$ than in those exposed to SDPP (17.1 $\pm 4.1 \mathrm{ng} / \mathrm{mL}$ ). Milk yield was inversely related to the magnitude of the periparturient PRL surge, but was directly related to the expression of PRL-receptor mRNA in lymphocytes during the dry period. Through $120 \mathrm{~d}$ of lactation, cows exposed to SDPP when dry produced more milk $(40.4 \pm 1.1 \mathrm{~kg} / \mathrm{d})$ than cows exposed to LDPP $(36.8 \pm 1.1 \mathrm{~kg} / \mathrm{d})$. These results support the concept that SDPP, combined with a targeted 42-d dry period, increases milk yield in the subsequent lactation, relative to a 42 -d dry period combined with LDPP, and that exposure to $42 \mathrm{~d}$ of SDPP in the dry period is sufficient to increase milk yield in the next lactation.

Key words: photoperiod, dry period, prolactin

\section{INTRODUCTION}

The dry period is a critical stage of the lactation cycle in dairy cows and is essential for achieving optimal milk yield in the subsequent lactation (Capuco et al., 1997; Bachman and Schairer, 2003). The duration of the dry period appears to be optimized at $60 \mathrm{~d}$, and fewer than $30 \mathrm{~d}$ can result in milk production loss in the next lactation (Grummer and Rastani, 2004; Kuhn et al., 2006). In the absence of a dry period, milk yield in the subsequent lactation can be reduced by as much as 20\% (reviewed in Capuco and Akers, 1999; Bachman and Schairer, 2003). There are, however, some advantages to reducing the dry period length, including increased income from milk in the current lactation, simplified management of dry cows through movement toward a one-group nutritional strategy, decreased metabolic disorders, and reduced strain on dry cow facilities (Grummer and Rastani, 2004). Therefore, recommendations for the optimal dry period length for cows are being reexamined.

One tool to enhance milk yield in the next lactation is to manipulate the photoperiod during the dry period. Miller et al. (2000) and Auchtung et al. (2005) reported that cows exposed to a short-day photoperiod (SDPP; 8 h light:16 h dark) during an entire 60-d dry period subsequently produced more milk than cows exposed to a long-day photoperiod (LDPP; $16 \mathrm{~h}$ light:8 $\mathrm{h}$ dark). The mechanism appears to be associated with 
differences in plasma prolactin (PRL) concentrations and prolactin receptor (PRL-R) mRNA expression in mammary epithelial cells and an increase in mammary cell growth (Wall et al., 2005a,b). However, the duration of light exposure required to enhance milk yield (i.e., the total number of days that cows need to be exposed to SDPP when dry) is less clear. Sixty days of exposure to SDPP during the dry period results in increased milk production (Auchtung et al., 2005), yet treatment with SDPP during the final $21 \mathrm{~d}$ of the dry period did not affect subsequent production (Reid et al., 2004). Therefore, the objective of the present study was to determine whether treatment with SDPP combined with a reduced dry-period length of $42 \mathrm{~d}$ would increase milk production in the subsequent lactation, compared with cows exposed to LDPP. In addition, the effects of photoperiod on DMI, PRL, and PRL-R mRNA expression in lymphocytes were investigated.

\section{MATERIALS AND METHODS}

\section{Experimental Design}

Forty multiparous Holstein cows from the University of Illinois dairy herd were enrolled in the study. All procedures and photoperiod manipulations were approved by the University of Illinois at Urbana-Champaign Institutional Animal Care and Use Committee. The cows were dried off $42 \mathrm{~d}$ before expected calving according to the standard University of Illinois dairy protocol, which consisted of infusion of each quarter of the mammary gland with intramammary antibiotic (Quartermaster, Pfizer, Kalamazoo, MI) and cessation of milking. Cows were randomly assigned to either the SDPP ( $=20)$ or LDPP $(n=20)$ treatment, and treatments were balanced by previous milk production (305-d mature equivalent) and expected calving date. Treatments began at dry-off, which occurred between May 26, 2005, and September 1, 2005, and continued until calving between July 1, 2005, and October 18, 2005. The mean calving dates were August 10, 2005, and August 20, 2005, for the SDPP and LDPP groups, respectively. During the dry period, cows were housed in a ventilated, enclosed barn with minimal external light. Lighting was provided by metal halide lights at approximately $250 \pm 10 \mathrm{~lx}$ at eye level of the cows. For the SDPP treatment, lights were on between 0800 and $1600 \mathrm{~h}$ daily. For the LDPP treatment, lights were turned on at $0800 \mathrm{~h}$ and off at $2400 \mathrm{~h}$ daily.

Cows had access to sand-bedded free stalls until $5 \mathrm{~d}$ before expected calving date, when they were moved to an individual maternity pen bedded with straw. After parturition, cows were moved to a tie-stall barn and maintained under ambient photoperiod conditions during the entire lactation. Cows were fed ad libitum during the dry period by using an individual Calan (American Calan, Northwood, $\mathrm{NH}$ ) gate feeding system. Relative to traditional diets fed during the far-off dry period, an energy-dense diet was fed to cows during the entire dry period in this study. The dry period diet was similar in composition and energy density to the lactation diet (Table 1). Refusals were weighed daily to calculate DMI, and daily values were combined to produce weekly averages. Dry matter intake, reported as a percentage of BW, was analyzed weekly during the dry period and through $42 \mathrm{~d}$ postcalving. Cows were weighed weekly, and BCS was estimated weekly during the dry period until $42 \mathrm{~d}$ after calving.

\section{Physical Examinations}

Body weight and BCS were measured weekly from dry off until $42 \mathrm{~d}$ after calving. Body condition score was measured on a 5-point scale (Ferguson et al., 1994). Each cow was given a comprehensive physical exam at dry-off, $21 \mathrm{~d}$ after dry-off, and at calving. Heart and respiratory rates, rectal temperature, rumen contraction rate, BCS, urinary ketones, udder characteristics, hydration state, consistency of mucous membranes, and occurrence of retained placenta during the dry period and at calving were determined. Calf BW was recorded at birth.

\section{Blood Collection and Assays}

Individual blood samples $(10 \mathrm{~mL})$ from each cow were collected weekly by jugular venipuncture at 0830 $\mathrm{h}$ during the dry period and at calving. Frequency of blood collection (tail vein) increased to twice daily, at 0900 and $2100 \mathrm{~h}$, starting $5 \mathrm{~d}$ before the expected calving date and continuing until $3 \mathrm{~d}$ after calving. Blood samples were collected by using sterile evacuated tubes containing sodium heparin (Vacutainer, Becton Dickinson and Co., Franklin Lakes, NJ) and were placed on ice immediately after collection. Within $2 \mathrm{~h}$ of collection, plasma was harvested from whole blood by centrifugation $\left(1,850 \times \mathrm{g}, 20 \mathrm{~min}, 4^{\circ} \mathrm{C}\right)$. Plasma was stored at $-20^{\circ} \mathrm{C}$ until concentrations of plasma PRL were determined by RIA as described by Miller et al. (1999). Interassay and intraassay overall coefficients of variation for the 5 assays were 8.82 and $15.44 \%$, respectively. Assay sensitivity averaged $1.14 \mathrm{ng} / \mathrm{mL}$. For PRL-R mRNA isolation, additional blood samples were taken (dry-off, $-21 \mathrm{~d}$, and calving) and total RNA was isolated from lymphocytes recovered from whole blood by using density gradient centrifugation through Histopaque-1077 (Sigma, St. Louis, MO) as described by Auchtung et al. (2003). Purification of RNA was 
conducted with the RNeasy Mini Kit (Qiagen, Valencia, CA), and residual DNA was removed by using the DNA-free procedure (Ambion, Austin, TX). Total RNA $(2.5 \mu \mathrm{g})$ was reverse transcribed to $21.5 \mu \mathrm{L}$ of cDNA by using the StrataScript First-Strand Synthesis System (Stratagene, La Jolla, CA). Real-time reverse transcription-PCR was performed with an ABI Prism 7900 HT instrument (Applied Biosystems, Foster City, CA). Forward and reverse primer sets for PRL-R, GAPDH, and 8 -actin were 5'-AGGCCCCTCAGAGCACAAG-3' and 5'-TGGGTCCATTGGCCAGAA-3', 5'-ACCAGAAGACTGTGGATGG-3' and 5'-CAACAGACACGTTGGGAGTG-3', and 5'-GGCATCCTGACCCTCAAGTA-3' and 5'-CACACGGAGCTCGTTGTAGA-3', respectively. Amplification mixes $(10 \mu \mathrm{L})$ contained $5 \mu \mathrm{L}$ of SYBR Green PCR Master Mix (Applied Biosystems), $1 \mu \mathrm{L}$ of cDNA, and 80 pmol of each primer. Reactions were run in triplicate, with PRL-R, GAPDH, and B-actin run in separate wells. A relative standard curve of 7 dilutions of cDNA derived from heifer mammary tissue was run in triplicate for each gene. Expression of PRL-R was normalized to each reference gene as described by Auchtung et al. (2003), and the geometric mean of the 2 normalized values was used for statistical analyses.

\section{Milk Production and Sampling}

After parturition, cows were milked twice daily throughout their lactation, and milk production was recorded daily electronically with PCDART (The Dairy Records Processing Center, Raleigh, NC) for 120 d postpartum. Daily milk yields were averaged to calculate weekly values. The $3.5 \%$ ECM was calculated by using the equation described by Tyrrell and Reid (1965). Milk samples were collected at dry-off, calving, and 3 and $7 \mathrm{~d}$ after calving, and then monthly until $120 \mathrm{~d}$ of

Table 1. Diet composition and analysis of the TMR fed to cows during the dry period and lactation

\begin{tabular}{|c|c|c|}
\hline Item & $\begin{array}{l}\text { Dry period } \\
\text { ration }\end{array}$ & $\begin{array}{l}\text { Lactation } \\
\text { ration }\end{array}$ \\
\hline \multicolumn{3}{|l|}{ Ingredient, \% of DM } \\
\hline Alfalfa hay & 5.8 & 5.8 \\
\hline Alfalfa silage & 13.6 & 13.6 \\
\hline Corn silage & 27.3 & 27.3 \\
\hline Soyhulls & 2.5 & 2.5 \\
\hline Cottonseed & 8.5 & 8.5 \\
\hline Wet brewers grains & 13.6 & 13.6 \\
\hline Corn (ground) & 21.4 & 21.4 \\
\hline Soybean meal (48\%) & 2.6 & 2.6 \\
\hline Soyhulls & 4.37 & 1.30 \\
\hline Sodium bicarbonate & - & 0.96 \\
\hline Limestone & - & 0.96 \\
\hline Dicalcium phosphate & - & 0.38 \\
\hline Biotin $100^{1}$ & 0.39 & 0.39 \\
\hline Magnesium oxide & 0.19 & 0.19 \\
\hline $\mathrm{U}$ of I premix ${ }^{2}$ & 0.23 & 0.23 \\
\hline $\mathrm{NaCl}$ & - & 0.19 \\
\hline \multicolumn{3}{|l|}{ Chemical composition, \% of DM } \\
\hline $\mathrm{DM}$ & 45.32 & 47.82 \\
\hline $\mathrm{CP}$ & 17.58 & 17.22 \\
\hline Available protein & 16.3 & 15.8 \\
\hline Acid detergent-insoluble $\mathrm{CP}$ & 1.36 & 1.47 \\
\hline $\mathrm{ADF}$ & 26.10 & 28.78 \\
\hline $\mathrm{NDF}$ & 37.70 & 38.37 \\
\hline Total digestible nutrients & 70.40 & 69.83 \\
\hline $\mathrm{NE}_{\mathrm{L}}, \mathrm{Mcal} / \mathrm{kg}$ & 1.68 & 1.65 \\
\hline Calcium & 0.73 & 0.76 \\
\hline Phosphorus & 0.49 & 0.45 \\
\hline Magnesium & 0.25 & 0.32 \\
\hline Potassium & 1.43 & 1.41 \\
\hline Sodium & 0.05 & 0.39 \\
\hline Iron, ppm & 299.0 & 298.0 \\
\hline Zinc, ppm & 105.0 & 101.8 \\
\hline Copper, ppm & 19.40 & 20.33 \\
\hline Manganese, ppm & 85.60 & 82.50 \\
\hline Molybdenum, ppm & 0.92 & 0.63 \\
\hline
\end{tabular}

${ }^{1}$ ADM Biotin 100, ADM Alliance Nutrition, Quincy, IL.

${ }^{2}$ Vitamin A, 2,200 IU/g; vitamin $\mathrm{D}_{3}$, $660 \mathrm{IU} / \mathrm{g}$; vitamin E, $80 \mathrm{IU} / \mathrm{g} ; \mathrm{I}, 0.025 \%$; Fe, 2.0\%; Mn, 3.0\%; Mg, 5.0\%; $\mathrm{Cu}, 0.5 \%$; Co, 0.004\%; Se, 0.015\%; S, 10.0\%; K, 7.5\%. 
Table 2. Milk yield, 3.5\% ECM yield, and milk components for the first $120 \mathrm{~d}$ of lactation in cows exposed to a short-day photoperiod (SDPP; $\mathrm{n}=17)$ or a long-day photoperiod (LDPP; $\mathrm{n}=17)$ during a targeted 42-d dry period

\begin{tabular}{lrrcc}
\hline Variable & SDPP & LDPP & SEM & $P$-value \\
\hline Milk, kg/d & 38.5 & 35.0 & 1.3 & 0.05 \\
ECM, kg/d & 40.4 & 36.8 & 1.1 & 0.04 \\
Fat, \% & 3.9 & 4.1 & 0.5 & 0.56 \\
Protein, \% & 3.1 & 3.2 & 0.1 & 0.48 \\
Lactose, \% & 4.9 & 4.7 & 0.2 & 0.35 \\
TS, \% & 12.5 & 12.8 & 0.5 & 0.43 \\
Other solids, \% & 5.7 & 5.6 & 0.1 & 0.27 \\
MUN, mg/dL & 16.7 & 12.3 & 3.5 & 0.06 \\
\hline
\end{tabular}

lactation for component analysis of fat, true protein, lactose, other solids, TS, MUN, and SCC (Foss 400; Dairy Laboratory Services Inc., Dubuque, IA). Aseptic milk samples were also collected according to National Mastitis Council (1999) protocols at dry-off and calving to assess IMI prevalence. Samples were plated in duplicate, and obvious growth was identified if present. If the same organism was identified in both duplicates, it was considered an infection.

\section{Statistical Analysis}

Statistical analyses were performed by using the SAS System v. 9.1 (SAS Institute Inc., Cary, NC). A mixed model with an autoregressive covariance structure was used to analyze data as repeated measures. Specific comparisons were made for milk production, ECM, DMI, plasma PRL concentration, PRL-R, BW, BCS, and milk composition between treatments across time. Models included the fixed effects of treatment, time, and treatment $\times$ time and the random effect of cow. Covariates of 305-d mature equivalent milk in the previous lactation and days dry were included in the model used to analyze milk and ECM production. Average daily ambient temperature was used as a covariate in the model for analyzing plasma PRL concentration. Standard error of the mean is reported. Significance was determined at $P<0.10$, and trends were determined at $P<0.15$.

\section{RESULTS}

\section{Milk Production and DMI}

A total of 6 cows, 3 from each treatment, were removed from the study after calving. One died at calving from uterine prolapse, 2 were culled because of severe mastitis ( 1 from each treatment), and 3 cows were dry for less than $5 \mathrm{wk}$. During the first $120 \mathrm{~d}$ of lactation, cows exposed to SDPP during the dry period produced $3.5 \mathrm{~kg} / \mathrm{d}$ more milk than cows on the LDPP treatment

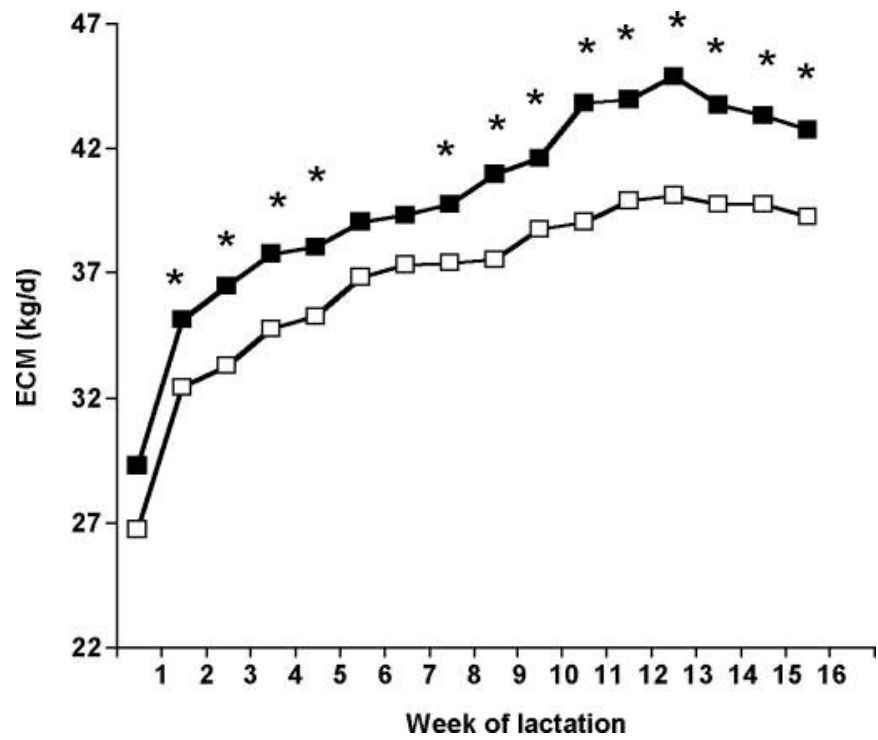

Figure 1. Effect of a short-day photoperiod (SDPP; $\mathrm{n}=17)$ or a long-day photoperiod (LDPP; $\mathrm{n}=17$ ) during a 42 -d dry period on the production of ECM during the following lactation. Solid squares (घ) represent cows exposed to SDPP and open squares () represent cows exposed to LDPP. Cows exposed to SDPP had greater ECM production than cows exposed to LDPP during the first 16 wk of lactation. ${ }^{*} P<0.05 ; \mathrm{SEM}=1.3 \mathrm{~kg} / \mathrm{d}$. Cows were exposed to an ambient photoperiod after parturition.

(Table 2; $P=0.05$ ). Production of ECM showed a pattern similar to actual milk production; cows exposed to SDPP produced $3.6 \mathrm{~kg} / \mathrm{d}$ more ECM than cows exposed to LDPP (Table 2 and Figure $1 ; P=0.04$ ). There was no difference between treatments in percentages of fat, protein, lactose, and solids in milk (Table 2). However, MUN concentration was greater in milk from cows exposed to SDPP than in cows exposed to LDPP (16.7 \pm 3.1 and $12.3 \pm 3.3 \mathrm{mg} / \mathrm{dL}$, respectively; $P=0.06$ ). There was no difference between treatments in SCC $(P=0.48)$. At dry-off, SCC for cows exposed to SDPP was $422 \pm 43.5 \times 10^{3}$ cells $/ \mathrm{mL}$, and for cows exposed to $\mathrm{LDPP}$ it was $590 \pm 78.5 \times 10^{3}$ cells $/ \mathrm{mL}$. At calving, SCC increased for both groups, but there was no difference between treatments $(P=0.55)$. Cows on SDPP had an $\mathrm{SCC}$ of $854 \pm 62.2 \times 10^{3}$ cells $/ \mathrm{mL}$ and LDPP cows had an SCC of $903 \pm 49.6 \times 10^{3}$ cells $/ \mathrm{mL}$. There was no difference between treatments in IMI prevalence of cows at dry-off or calving: 22.3 infected quarters for cows on SDPP versus 19.7 infected quarters for cows on LDPP, and 36.2 versus 31.6 infected quarters, respectively ( $P$ $\geq 0.5$ ). The most common pathogens isolated included Staphylococcus spp. (Staphylococcus aureus, chromogenes, and muscae) and Streptococcus agalactiae.

Overall DMI during the $42 \mathrm{~d}$ of the dry period was greater for cows exposed to SDPP than cows exposed to LDPP $(P \leq 0.10)$, and this increase was particularly 


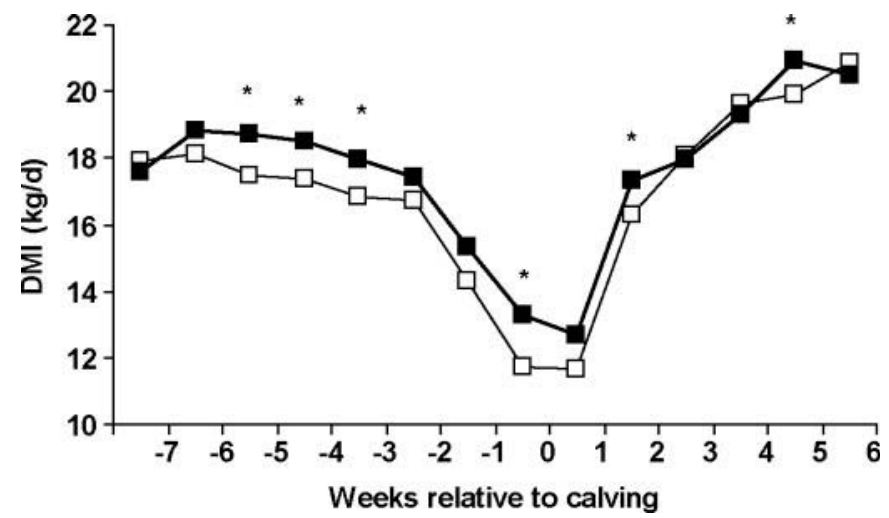

Figure 2. Effect of photoperiod during a 42-d dry period on DMI before and after calving in cows exposed to a short-day photoperiod (SDPP) or a long-day photoperiod (LDPP) during a 42-d dry period. Solid squares (-) represent cows exposed to SDPP ( $\mathrm{n}=18$ before and $\mathrm{n}=17$ after calving) and open squares ( $\square$ ) represent cows exposed to LDPP ( $\mathrm{n}=18$ before and $\mathrm{n}=17$ after calving, respectively). Cows on the SDPP treatment had greater DMI than cows on the LDPP treatment during the dry period $\left({ }^{*} P<0.05 ;\right.$ SEM $\left.=1.1 \mathrm{~kg} / \mathrm{d}\right)$, and there was no difference between treatments after calving $(P>0.15$; $\mathrm{SEM}=1.4 \mathrm{~kg} / \mathrm{d}$ ). Cows were exposed to an ambient photoperiod after parturition.

noted early in the dry period (Figure 2). Dry matter intake as a percentage of BW did not differ between cows exposed to SDPP and LDPP $(P>0.5)$ but was numerically greater in cows on the SDPP treatment (data not shown). Overall DMI after calving did not differ between treatments during the first $42 \mathrm{~d}$ of lactation (Figure 2; $P>0.15$ ); however, in the second and fifth week of lactation, cows exposed to SDPP during the dry period had greater DMI than cows exposed to LDPP during the dry period $(P=0.10)$. Body weight did not differ between cows exposed to SDPP or LDPP during the dry period ( $743 \pm 18 \mathrm{vs} .739 \pm 16 \mathrm{~kg}$, respectively) or during the $42 \mathrm{~d}$ after parturition ( $749 \pm 21$ vs. $730 \pm 25$ $\mathrm{kg}$, respectively; $P>0.5$ ). Body condition score during the dry period did not differ between treatments (BCS $=3.0 \pm 0.3 ; P>0.5)$. During the first $42 \mathrm{~d}$ of lactation, cows on the SDPP treatment tended to have higher BCS $(2.8 \pm 0.3)$ than cows on the LDPP treatment (2.6 $\pm 0.2 ; P \leq 0.15)$.

\section{PRL and PRL-R}

Plasma PRL concentrations did not differ between treatments at dry-off $(P>0.15)$. However, the plasma PRL concentration of cows on the SDPP treatment (11.2 $\pm 4.5 \mathrm{ng} / \mathrm{mL}$ ) was significantly lower than that of cows exposed to LDPP $(16.9 \pm 5.3 \mathrm{ng} / \mathrm{mL}) 21 \mathrm{~d}$ after dry-off $(P<0.04)$. During the periparturient period of -6 to +4 $\mathrm{d}$ relative to calving, cows exposed to LDPP averaged $22.6 \pm 3.9 \mathrm{ng} / \mathrm{mL}$ of PRL, and cows exposed to SDPP averaged $17.1 \pm 4.1 \mathrm{ng} / \mathrm{mL}(P<0.05$; Figure 3$)$. Within

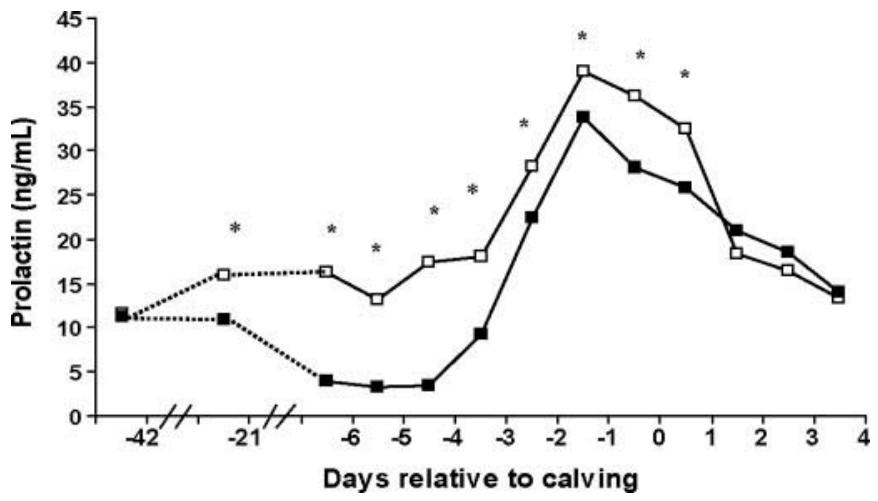

Figure 3. Effect of photoperiod manipulation on prolactin (PRL) concentration before and after calving. Solid squares ( $\mathbf{-})$ represent a short-day photoperiod treatment (SDPP; $\mathrm{n}=15)$ and open squares ( $\square$ ) represent a long-day photoperiod treatment (LDPP; $n=15)$. The days dry represent the times relative to expected calving date. Cows exposed to LDPP had greater PRL concentrations than cows exposed to SDPP. ${ }^{*} P<0.05$; SEM $=4.81 \mathrm{ng} / \mathrm{mL}$. Cows were exposed to an ambient photoperiod after parturition.

the first $4 \mathrm{~d}$ of lactation, plasma PRL concentrations declined in both groups and were not different.

Expression of PRL-R mRNA in lymphocytes is presented in Figure 4. Relative to dry-off, PRL-R expression at $21 \mathrm{~d}$ for LDPP-treated cows was $107 \%$ and for SDPP-treated cows was 170\%. At calving, PRL-R expression for LDPP-treated cows was 106\% and for SDPP-treated cows was 200\%. The cows exposed to SDPP had greater PRL-R mRNA expression $21 \mathrm{~d}$ after dry-off and at calving $(P<0.05)$ relative to the cows exposed to LDPP.

\section{Dry Period Length, Calf Weight, and Physical Examinations}

The actual dry period length for cows exposed to SDPP was $5 \mathrm{~d}$ shorter compared with cows on the LDPP treatment (37 vs. $42 \mathrm{~d}$, respectively; $P=0.08$ ). Calf BW at birth did not differ between treatments $(P>0.2)$. No treatment differences were observed in health parameters at dry-off, at $21 \mathrm{~d}$ after dry-off, or at calving.

\section{DISCUSSION}

Results of this study confirm that exposure of cows to SDPP during a targeted 42-d dry period increased milk production in the subsequent lactation compared with cows exposed to LDPP. This observation is consistent with previous studies comparing treatment with SDPP to treatment with LDPP during a 60-d dry period (Miller et al., 2000; Dahl and Petitclerc, 2003; Auchtung et al., 2005). In this study, milk composition was not affected by photoperiod treatment, which is similar 
to previous results (Miller et al., 2000; Auchtung et al., 2005; Crawford et al., 2005). However, these data demonstrate that as few as $42 \mathrm{~d}$ of targeted exposure to SDPP during the dry period is sufficient to increase milk production in the subsequent lactation.

Previous research has indicated that the increase in milk production of cows exposed to SDPP may in part be due to an increase in DMI during the dry period, because cows exposed to SDPP had greater DMI compared with those cows exposed to LDPP when dry (Miller et al., 2000; Reid et al., 2004; Auchtung et al., 2005; Crawford et al., 2005). In this study, cows on the SDPP treatment consumed more DM during the dry period than did cows on the LDPP treatment. However, there was no difference between treatments when DMI was analyzed as a percentage of BW, a result similar to that of Crawford et al. (2005). Therefore, if greater DMI during the dry period is involved in the increase in subsequent milk yield of cows exposed to SDPP relative to cows exposed to LDPP, it is likely a supportive role. After parturition, there was some indication that cows exposed to SDPP when dry had increased DMI, although this was not consistent during the initial 42 DIM. Because they produced more milk relative to LDPP cows, it is possible that cows in the SDPP treatment experienced a more profound negative energy balance. The relative importance of this slight negative energy balance, however, is unknown because it did not influence their capacity to support greater yields.

Grummer and Rastani (2004) reported that the milk yield response to a short dry period is variable, suggesting that there may be differences among individual animals, interactions between management practices, and effects of length of the dry period. In this study, only one diet was fed, which was relatively energy dense compared with typical dry cow diets. Elimination of a far-off dry period diet means that it is possible to feed a more uniform diet throughout the pregnancy-lactation cycle. Fewer dietary shifts could result in fewer feedrelated problems during the transition period and thus reduce the stress of dietary changes around parturition. In addition, fewer dietary changes during a short dry period length may encourage maintenance of a more stable rumen microbial population and better development of rumen papillae (Dirksen et al., 1985). The present results suggest that shortening the dry period and feeding only one diet does not negatively influence the cow's ability to respond to photoperiod manipulation and supports the concept that a short dry period simplifies dietary management of the dry cows.

Previous photoperiod research has shown a consistent alteration of the PRL signaling axis, with exposure to SDPP resulting in increases in PRL sensitivity compared with exposure to LDPP. This drives changes

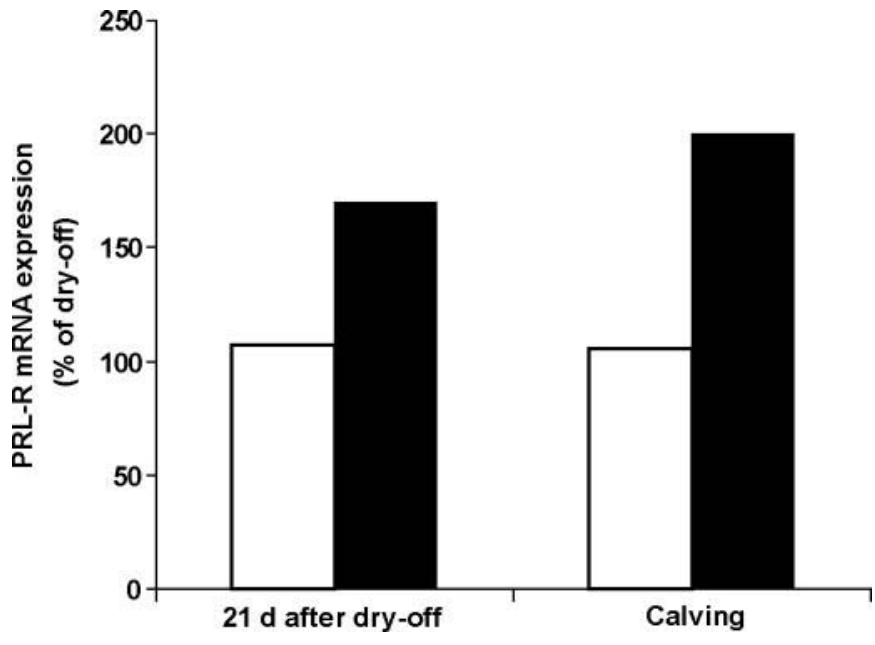

Figure 4. Effect of photoperiod manipulation during a 42-d dry period on prolactin receptor (PRL-R) mRNA expression in lymphocytes. Expression of PRL-R mRNA at $21 \mathrm{~d}$ after dry-off and calving relative to baseline expression at dry-off is shown in the figure. Solid bars (घ) represent the short-day photoperiod treatment (SDPP; $\mathrm{n}=$ 11) and open bars (口) represent the long-day photoperiod treatment (LDPP; $\mathrm{n}=11$ ). Cows exposed to SDPP had greater PRL-R mRNA expression $21 \mathrm{~d}$ after dry-off and at calving compared with cows exposed to LDPP $(P<0.05 ; \mathrm{SEM}=18.3)$.

in mammary gland function of cows exposed to SDPP to support the increase in milk production in the subsequent lactation (Auchtung et al., 2005; Wall et al., 2005a,b). In the present study, cows exposed to LDPP during the dry period had greater plasma PRL concentrations than those exposed to SDPP, a finding similar to those of previous studies in heifers (Newbold et al., 1991) and dry cows (Miller et al., 2000; Auchtung et al., 2005; Crawford et al., 2005). An inverse relationship between PRL and PRL-R mRNA expression in mammary, immune, and hepatic tissues was observed previously in cattle (Auchtung et al., 2003, 2005; Crawford et al., 2005), and in this study, cows exposed to LDPP had greater plasma PRL concentrations and lower lymphocyte PRL-R mRNA expression at $21 \mathrm{~d}$ post dry-off and calving, relative to cows exposed to SDPP. The PRL and PRL-R results are consistent with those reported by Wall et al. (2005a), who found that mammary tissue proliferation during the dry period was associated with an increase in mammary PRL-R expression. Results of the present study suggest that a 42-d planned exposure to SDPP is sufficient to produce the improvements in mammary cell proliferation observed previously.

\section{CONCLUSIONS}

Treatment of cows with a reduced dry period length of $42 \mathrm{~d}$ can be combined with exposure to SDPP to improve milk production in the subsequent lacta- 
tion compared with an LDPP treatment. This study provides evidence that a reduced dry period length of $42 \mathrm{~d}$ has no negative effects on DMI, BW, BCS, and health parameters during the immediate postpartum period (3 $\mathrm{d}$ after calving). Relative to a conventional 60-d dry period, this management approach increases the income from milk production in the current lactation, simplifies dry cow management, and alleviates the stress of overcrowded dry cow facilities.

\section{REFERENCES}

Auchtung, T. L., P. E. Kendall, J. L. Salak-Johnson, T. B. McFadden, and G. E. Dahl. 2003. Photoperiod and bromocriptine treatment effects on expression of prolactin receptor mRNA in bovine liver, mammary gland and peripheral blood lymphocytes. J. Endocrinol. 179:347-356.

Auchtung, T. L., A. G. Rius, P. E. Kendall, T. B. McFadden, and G. E. Dahl. 2005. Effects of photoperiod during the dry period on prolactin, prolactin receptor, and milk production of dairy cows. J. Dairy Sci. 88:121-127.

Bachman, K. C., and M. L. Schairer. 2003. Invited review: Bovine studies on optimal lengths of dry periods. J. Dairy Sci. 86:30273037.

Capuco, A. V., and R. M. Akers. 1999. Mammary involution in dairy animals. J. Mammary Gland Biol. Neoplasia 4:137-144.

Capuco, A. V., R. M. Akers, and J. J. Smith. 1997. Mammary growth in Holstein cows during the dry period: Quantification of nucleic acids and histology. J. Dairy Sci. 80:477-487.

Crawford, H. M., J. L. Dauderman, D. E. Morin, T. B. McFadden, and G. E. Dahl. 2005. Evidence of a role of prolactin in mediating photoperiodic effects during the dry period. J. Dairy Sci. 88(Suppl. 1):363. (Abstr.)

Dahl, G. E., and D. Petitclerc. 2003. Management of photoperiod in the dairy herd for improved production and health. J. Anim. Sci. 81(Suppl. 3):11-17.
Dirksen, G. U., G. H. Liebich, and E. Mayer. 1985. Adaptive changes of the ruminal mucosa and their functional and clinical significance. Bov. Pract. 20:116-120.

Ferguson, J. D., D. T. Galligan, and N. Thomsen. 1994. Principal descriptors of body condition score in Holstein cows. J. Dairy Sci. 77:2695-2703.

Grummer, R.R., and R.R. Rastani. 2004. Why reevaluate dry period length? J. Dairy Sci. 87(E Suppl.):E77-E85.

Kuhn, M. T., J. L. Hutchison, and H. D. Norman. 2006. Dry period length to maximize production across adjacent lactations and lifetime production. J. Dairy Sci. 89:1713-1722.

Miller, A. R., R. A. Erdman, L. W. Douglass, and G. E. Dahl. 2000. Effects of photoperiodic manipulation during the dry period of dairy cows. J. Dairy Sci. 83:962-967.

Miller, A. R. E., E. P. Stanisiewski, R. A. Erdman, L. W. Douglass, and G. E. Dahl. 1999. Effects of long daily photoperiod and bovine somatotropin $\left(\right.$ Trobest $^{\mathbb{B}}$ ) on milk yield in cows. J. Dairy Sci. 82:1716-1722.

National Mastitis Council. 1999. Laboratory Handbook on Bovine Mastitis. National Mastitis Council Inc., Madison, WI.

Newbold, J. A., L. T. Chapin, S. A. Zinn, and H. A. Tucker. 1991. Effects of photoperiod on mammary development and concentration of hormones in serum of pregnant dairy heifers. J. Dairy Sci. 74:100-108.

Reid, E. D., R. L. Wallace, T. B. McFadden, and G. E. Dahl. 2004 The effects of a 21-day short photoperiod treatment during the dry period on dry matter intake and subsequent milk production in cows. J. Dairy Sci. 87(Suppl. 1):424. (Abstr.)

Tyrrell, H. F., and J. T. Reid. 1965. Prediction of the energy value of cow's milk. J. Dairy Sci. 48:1215-1223.

Wall, E. H., T. L. Auchtung, G. E. Dahl, S. E. Ellis, and T. B McFadden. 2005a. Exposure to short day photoperiod during the dry period enhances mammary growth in dairy cows. J. Dairy Sci. 88:1994-2003.

Wall, E. H., T. L. Auchtung-Montgomery, G. E. Dahl, and T. B. McFadden. 2005b. Short Communication: Short day photoperiod during the dry period decreases expression of suppressors of cytokine signaling in the mammary gland of dairy cows. J. Dairy Sci. 88:3145-3148. 